\title{
Effects of Different Levels of Eucalyptus Oil on Methane Production under in vitro Conditions
}

\author{
Safwat Mohammed Abdelrahman ${ }^{1}$, Run-Hang Li ${ }^{1}$, Mostafa Elnahr ${ }^{1}$, \\ Mohammed Hamdy Farouk ${ }^{1,2}$, Yujie Lou ${ }^{1 * *}$
}

${ }^{1}$ College of Animal Science and Technology, Jilin Agricultural University, Changchun City, China ${ }^{2}$ Animal Production Department, Faculty of Agriculture, Al-Azhar University, Nasr City, Cairo, Egypt

Received: 20 January 2018

Accepted: 1 March 2018

\begin{abstract}
Livestock animals are seriously contributing to global warming as methane producers. Six levels $\left(0,2,4,6,8\right.$, and $\left.10 \mathrm{ml} \cdot \mathrm{kg}^{-1} \mathrm{DM}\right)$ of eucalyptus oil (EuO) were investigated under in vitro conditions to study the mitigation ability for methane production, using two rations: R1 ( $70 \%$ forage: $30 \%$ concentrates) and R2 (60\% forage: $40 \%$ concentrates). Two cannulated sheep were used as donor animals to obtain the rumen liquid. The results showed that $\mathrm{CH}_{4}$ production levels were significantly $(P \leq 0.05)$ lower in all treated groups with $\mathrm{EuO}$ than the control group $\left(0 \mathrm{ml} . \mathrm{kg}^{-1} \mathrm{DM}\right)$ in both rations. The retreating for $\mathrm{CH}_{4}$ of $\mathrm{R} 1$ was $32 \%$, adding of $2 \mathrm{~mL} \cdot \mathrm{kg}^{-1} \mathrm{DM}$, and was $38 \%$ in $10 \mathrm{ml} . \mathrm{kg}^{-1} \mathrm{DM}$. Regarding R2, the decrease ratio of methane production was $42 \%$ in $2.0 \mathrm{~mL}$ addition, whereas it was $46 \%$ in $10 \mathrm{~mL}$ of addition rate. In $\mathrm{R} 2$, protozoa count was significantly $(P \leq 0.05)$ lower by adding the eucalyptus oil compared with the control. In conclusion, using EuO and a high-protein diet could decrease both total gas volume and methane production even with minimal oil levels $\left(2.0 \mathrm{~mL}\right.$ EuO. $\left.\mathrm{kg}^{-1} \mathrm{DM}\right)$. It is recommended to carry out an in vivo experiment to emphasize the effects of $\mathrm{EuO}$ on the ruminant.
\end{abstract}

Keywords: essential oils, global warming, greenhouse gases, methane mitigation, sheep

\section{Introduction}

Greenhouse gases (GHG) are the prime determinant of global warming phenomena. The main ingredients of GHG are carbon dioxide $\left(\mathrm{CO}_{2}\right)$, nitrogen dioxide $\left(\mathrm{NO}_{2}\right)$, and methane $\left(\mathrm{CH}_{4}\right)$. According to the predictions of the Intergovernmental Panel on Climate Change (IPCC), the surficial temperature is going to increase $1.8-4.0^{\circ} \mathrm{C}$ by 2050 [1]. Interestingly, methane is one of the final

*e-mail: mhfarouk@azhar.edu.eg

**e-mail: lyjjlau@163.com products, which is produced as a result of the degradation of organic matter (OM), especially carbohydrates in the fore-stomach chamber in ruminants. Furthermore, it is the highest contributor to climate change [2, 3]. The increase of $\mathrm{CH}_{4}$ is going to run on the production of another serious gas, and the troposphere ozone and human activities are responsible for approximately 70\% of global methane [4]. In addition, methane has a more hazardous effect than $\mathrm{CO}_{2}$ since it binds the earthly warmth 20 times more than $\mathrm{CO}_{2}$ [5]. This gas is firmly squandering to the feed energy [2].

The livestock sector has an essential role in the current global warming problem, since the gas emission from the ruminants is representing about 
$14.5 \%$ of the total sources of GHG emissions all over the world [6]. The annual global emissions of methane from ruminant animals are approximately 80 million tons of methane [7]. The livestock sector contributes in GHG emissions directly and indirectly. According to the direct contribution, it points to the emissions from the dung, and from fermentation in the fore-stomach, which releases gasses like $\mathrm{CO}_{2}$ and $\mathrm{CH}_{4}$ [8]. Meat production from cattle has shown expansion of approximately $40 \%$ to face the growing demand in the world [9]. Animal products are predicted to have more demands by 2050 (74\% of milk and $58 \%$ of meat than what is currently required) [10]. Therefore, Washington, et al. [11] recommended that there should be concerted efforts between the experts of global warming, nature of the risk, and advanced program to count the risk.

Numbers of in vitro studies have demonstrated that essential oils (EO) or their components have the potential to favorably alter rumen metabolism [12-14]. The commercial blend of EO constrained the termination scale of amino groups for the amino acids under in vitro conditions [12]. Hence, garlic oil could stimulate monensin through decreasing the ratio of acetate to propionate. In this connection, Busquet, et al. [15] and Chiquette and Benchaar [16] showed the inhibitory effects of garlic oil and juniper berry EO on the production of methane in vitro. Sallam, et al. [14] reported that the use of eucalyptus oil could decrease gas production (GP). Eucalyptus oil was also investigated under in vitro conditions and reduced methane emissions until $56 \%$ in the study of Kumar, et al. [17]. In consistent, Manh, et al. [18] found that the supplementing treatment of eucalyptus oil at 100 g.head. $\mathrm{d}^{-1}$ for ruminants could be a feed enhancer for reducing methane gas production in cattle without any disorder of digestibility, whereas the most relevant studies were conducted to compare the $\mathrm{EuO}$ with other essential oils with no suggestion for specific or optimal oil levels [14, 17, 19]. Thus, the effects of different EuO levels on methane emission are not well characterized. Moreover, the roughage-toconcentrate ratio can affect the methanogenesis process [20]. This study hypothesizes that diet type (roughage to concentrate level) and the oil level of EuO can lower methane production in ruminant animals.

Therefore, the current study aims to evaluate the effect of different levels of eucalyptus oil on methane production performance and some ruminal metabolites using two ratios of roughage-to-concentrates (diet type) under in vitro conditions as a basis for the in vivo application.

\section{Material and Methods}

\section{Treatments and Experimental Design}

The current experiment was designed under in vitro conditions. All incubations were simultaneously conducted using 4 replications in each group and repeated three times. The eucalyptos oil (EuO) was extracted from E. camaldulensis species (purity $>990$ g/kg; Rongsheng Ltd. Co., Xi'an, China). Control and five levels of $\mathrm{EuO}$ were investigated as follows:

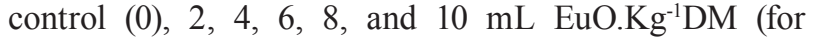
$1 \mathrm{~kg}$ Dry matter). A total mixed ration of forage-toconcentrates was supplemented under two different rations (diet type): R1 (70\% forage: $30 \%$ concentrates) and R2 (60\% forage: $40 \%$ concentrates). The artificial saliva buffer was prepared according to Menke and Steingass [21]. Briefly, the ruminal liquor was obtained from two cannulated Merino-type male sheep (weighing about $50 \mathrm{~kg}$ ), before the morning feeding in a pre-warmed $\left(39^{\circ} \mathrm{C}\right)$ thermos, and saturated with $\mathrm{CO}_{2}$. The collected liquids of two sheep were mixed and filtrated through double layers of gauze (pore size $355 \mu \mathrm{m})$. A total of $1 \mathrm{~g}$ of the diet (R1 or R2) was inserted into an incubation vial. Then the artificial saliva buffer was further mixed with the filtrated rumen liquid as 2:1 (v/v). Subsequently, a $75 \mathrm{~mL}$ from this mix was added to a $100 \mathrm{~mL}$ vial, which has been exposed to a stream of $\mathrm{CO}_{2}$, then closed with a rubber stopper.

Sheep were fed a roughage-based maintenance diet containing Aeurolepidium chinese hay, which contains $91.5 \%$ dry matter (DM), $8.1 \%$ crude protein (CP), 3.9\% ether extract (EE), 32.1\% crude fibres (CF), and 5\% ash and $1 \mathrm{~kg}$ concentrate (17\% CP, 22.7\% NDF, 33\% NFC, $1.81 \% \mathrm{NE}$, and $78.60 \% \mathrm{TDN}$ ) consisting of corn, DDGS, sugar beet meal, corn germ meal, corn gluten feed, soybean hulls, molasses, mineral mixture, and salt. This concentrated mix was offered two times daily to the animals that were separately housed in two stalls. The chemical compositions of the feedstuff are presented in Table 1.

\section{The Incubation Process}

Incubation began by placing the vials in a water bath shaker at $39^{\circ} \mathrm{C}$ for $72 \mathrm{~h}$. The gas production (GP) levels were detected at $3,6,12,24,36,48$, and $72 \mathrm{~h}$ during the incubation by inserting a $0.6 \mathrm{~mm}$ needle attached to a pressure transducer (model 2000A4, Xian special instrument, China) as described by Nanon, et al. [22]. The incubation was terminated after $72 \mathrm{~h}$ and the collected gas samples were immediately injected into a gas chromatograph (model Agilent 7890 A, US) for methane concentrations detection. The liquid samples were preserved at $-20^{\circ} \mathrm{C}$ for measuring ammonia and volatile fatty acid (VFA).

$$
\begin{aligned}
& \text { Estimating pH, Volatile Fatty Scids (VFAs), } \\
& \qquad \mathrm{NH}_{3}-\mathrm{N}
\end{aligned}
$$

The $\mathrm{pH}$ value was detected immediately after incubation termination using a $\mathrm{pH}$ meter. The gas samples were collected and injected into a GC instrument to detect the methane concentration using an Agilent 7980A GC system according to Nanon, et al. [22]. The incubated samples were centrifuged at $9000 \times \mathrm{g}$ 
Table 1. Chemical composition of feedstuff.

\begin{tabular}{|c|c|c|}
\hline Item & Concentrate & $\begin{array}{c}\text { Aeurolepidium } \\
\text { chinese }\end{array}$ \\
\hline Ingredient composition & $\begin{array}{c}\text { (\% DM } \\
\text { basis) }\end{array}$ & \\
\hline Corn & 18.00 & \\
\hline DDGS & 3.50 & \\
\hline Rice bran meal & 7.00 & \\
\hline Sugar beet meal & 9.00 & \\
\hline Corn germ meal & 10.50 & \\
\hline Corn gluten feed & 40.00 & \\
\hline Soybean Hulls & 5.00 & \\
\hline Molasses & 2.00 & \\
\hline Premix & 5.00 & \\
\hline Chemical composition & $(\%$ DM & \\
\hline bet energy (MJ/kg) & 1.81 & 1.56 \\
\hline Dry matter (\%) & 91.5 & 88.30 \\
\hline Crude protein (\%) & 17.00 & 3.20 \\
\hline NDF (\%) & 22.70 & 76.02 \\
\hline Ca (\%) & 0.78 & 0.25 \\
\hline P (\%) & 0.74 & 0.18 \\
\hline
\end{tabular}

for 10 minutes. The supernatant liquid was treated with $25 \%$ meta-phosphoric acid at a ratio of 5:1 (v/v). The mixture was centrifuged at $10000 \mathrm{x} g$ for 20 minutes. An aliquot of $1 \mathrm{~mL}$ supernatant was added to a gas chromatogram vial and placed in an autoanalyzer gas chromatograph (Agilent, 7980A GC system) according to Erwin, et al. [23]. The $\mathrm{NH}_{3}-\mathrm{N}$ concentration was measured according to Preston [24]. The VFA was measured as described by Shingfield, et al. [25].

\section{Feed Degradation}

The contents of the incubation vials were filtered into previously weighed sintered crucibles (100-160 $\mu \mathrm{m}$ pore size). The crucibles were washed with hot distilled water. Expressed as g. $\mathrm{kg}^{-1}$ of in vitro dry matter apparently digested (DMD) and organic matter apparently digested (OMD), were determined by the weight difference of non-degraded filtered residue following oven-drying $\left(100^{\circ} \mathrm{C}\right)$ and ashing $\left(500^{\circ} \mathrm{C}\right)$. The residual $\mathrm{DM}$ and ash were determined. The ratio of organic matter truly degraded (mg) to gas volume $(\mathrm{ml})$ at $72 \mathrm{~h}$ incubation was used as an index of microbial synthesis efficiency. Partitioning factor (PF) was calculated according to Blümmel, et al. [26] as the following:

$$
\mathrm{PF}=\mathrm{OMD}(\mathrm{mg}) / \mathrm{GP}(\mathrm{mL}) \text {. }
$$

\section{Protozoal Count}

Protozoa count was performed using a microscope according to the method of Kamra, et al. [27]. Counting solution was prepared as follows: a sample of $5 \mathrm{~mL}$ of rumen liquor was taken into a test-tube containing 5 $\mathrm{mL}$ formalinized physiological saline $(0.85 \%$ sodium chloride solution containing $20 \%$ formaldehyde). Two drops of methyl green dye ( $2 \mathrm{~g}$ methyl green and 2 $\mathrm{mL}$ glacial acetic acid diluted to $100 \mathrm{~mL}$ with distilled water) were added to the prepared counting solution, and then protozoa were counted.

Statistical analysis

All data in this study were subjected to general linear model (GLM) univariate analysis of variance (2-way analysis of variance with interaction) using SAS computer software [28] under the following statistical model:

$$
\mathrm{y}_{\mathrm{ijk}}=\mu+\operatorname{diet}_{\mathrm{i}}+\mathrm{O}_{\mathrm{ilj}}+\left(\text { diet*oil }_{\mathrm{ij}}+\mathrm{e}_{\mathrm{ijk}}\right.
$$

...where:

$\mathrm{y}_{\mathrm{ijk}}-$ the observation

$\mu$ - the overall mean

$\mathrm{O}_{\mathrm{ilj}}$ - the effect due to i-th level of treatment

diet $_{\mathrm{i}}$ - the effect due to the $\mathrm{j}$-th level of diet

(diet*oil $)_{\mathrm{ij}}$ - the effect due to the $\mathrm{j}$-th level of treatment within the i-the level of diet

$\mathrm{e}_{\mathrm{ijk}}$ - the observed error

The results are presented as least square mean (LSM) \pm SEM. Differences between means were assessed using Tukey's post hoc test and effects with a probability $(p)$ of $\leq 0.05$ were considered significant.

\section{Results and Discussion}

The metabolism and abundance of the microbial community in the rumen are representing the strategies to decrease methane production by the biological characteristics of the feedstuff. Such decreased methane should take place with least alteration effect for the fermentation processes. Many studies were performed to examine the potency of plant extracts to manipulate rumen microflora [29]. The herein study showed a decrease in total gas production and methane concentrations with minimal adverse fermentation effect using different levels of EuO with two ration-toconcentrate diets. Moreover, the highest concentrated ration was lower in methane production.

\section{Total Gas Production}

The diet-type overall of gas pressure was significantly higher in $\mathrm{R} 1$ than in $\mathrm{R} 2(\mathrm{~F}=49.80$; $p<0.0001)$. Regarding oil-level overall, the gas pressure was higher at the control level, whereas the lower control level was observed at the level of $10.0 \mathrm{~mL} \mathrm{EuO}$ with no significant differences $(\mathrm{F}=1.66 ; p=0.1486)$. 
Table 2. Effects of different levels of eucalyptus oil on gas production $(\mathrm{mL})$ under two types of rations.

\begin{tabular}{|c|c|c|c|}
\hline Item & \multicolumn{2}{|c|}{ Diet } & \multirow{2}{*}{$\begin{array}{c}\text { Oil-level } \\
\text { overall }\end{array}$} \\
\hline $\begin{array}{l}\text { Oil level } \\
(\mathrm{mL})\end{array}$ & R1 & R2 & \\
\hline 0.0 (Control) & $97.07 \pm 0.72$ & $92.71 \pm 0.68$ & $94.89 \pm 0.66$ \\
\hline 0.2 & $95.28 \pm 0.71$ & $92.56 \pm 0.68$ & $93.92 \pm 0.56$ \\
\hline 0.4 & $95.53 \pm 0.82$ & $92.60 \pm 0.72$ & $94.07 \pm 0.61$ \\
\hline 0.6 & $95.20 \pm 0.72$ & $92.33 \pm 0.71$ & $93.77 \pm 0.58$ \\
\hline 0.8 & $94.90 \pm 0.78$ & $92.25 \pm 0.71$ & $93.58 \pm 0.58$ \\
\hline 10.0 & $94.00 \pm 0.75$ & $91.72 \pm 0.67$ & $92.86 \pm 0.55$ \\
\hline $\begin{array}{c}\text { Diet-type } \\
\text { overall }\end{array}$ & $95.33^{\mathrm{A}} \pm 0.29$ & $92.36^{\mathrm{B}} \pm 0.29$ & \\
\hline HSD & \multicolumn{2}{|c|}{0.831} & 2.105 \\
\hline $\begin{array}{l}\text { HSD of } \\
\text { interaction }\end{array}$ & \multicolumn{2}{|c|}{3.426} & \\
\hline
\end{tabular}

$\mathrm{R} 1=70 \%$ forage: $30 \%$ concentrates; $\mathrm{R} 2=60 \%$ forage: $40 \%$ concentrates; Means with different superscripts are significantly different $(p \leq 0.05)$.

No interaction was detected between the main effects $(\mathrm{F}=0.49 ; p=0.7846)$ (Table 2).

A similar result was reported by Cobellis, et al. [30] since the TGP level was depressed to $5 \%$ compared with the control using $1.125 \mathrm{~mL} / \mathrm{L}$ of $\mathrm{EuO} / \mathrm{L}$, while Kouazounde, et al. [19] found that TGP level decreased to $15 \%$ in comparison with control, using $400 \mathrm{mg} / \mathrm{L}$ buffer of EuO. Moreover, Sallam, et al. [14] found that TGP level decreased to $56.7 \%$ compared to the control, using $75 \mathrm{~mL}$ buffer. In contrast, Cobellis, et al. [31] found that rosemary essential oil had no effect on the value of total gas production under low doses $(0.5$ $\mathrm{g} / \mathrm{L}$ of the incubated serum). Also Roy, et al. [32] found that cinnamon oil had no effect on total gas production under in vitro conditions.

\section{Methane Concentration}

The diet-type overall of methane concentration was significantly higher in $\mathrm{R} 1$ than in $\mathrm{R} 2(\mathrm{~F}=43.10$; $p<0.0001)$. Regarding the oil-level overall, the methane concentration was significantly higher at the control level, whereas the lower control level was observed at

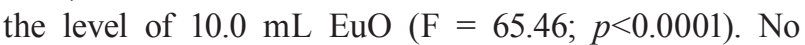
significant interaction was found between the diet and the oil effect $(\mathrm{F}=1.47 ; p=0.2049)$ (Table 3).

The results of this study are lower than the findings of Tatsuoka, et al. [33], who found that methane concentration decreased to $70 \%$ using $20 \mathrm{mg} / 60 \mathrm{~mL}$ buffer in $\mathrm{EuO}$ alfa cyclodextrin, while this percentage reached $85 \%$ using $10 \mathrm{~mL} \mathrm{mg} / 60 \mathrm{~mL} \mathrm{EuO} \mathrm{in} \mathrm{EuO}$ beta cyclodextrin. Also, our results were lower than that ratio $(90.3 \%)$ of Sallam, et al. [14]. While our results were higher than other relevant studies $(11 \%,[19] ; 18.7 \%$,
Table 3. Effects of different levels of eucalyptus oil on methane concentrations (ppm) under two types of rations.

\begin{tabular}{|c|c|c|c|}
\hline Item & \multicolumn{2}{|c|}{ Diet } & \multirow{2}{*}{$\begin{array}{c}\text { Oil-level } \\
\text { overall }\end{array}$} \\
\hline $\begin{array}{l}\text { Oil level } \\
(\mathrm{mL})\end{array}$ & R1 & $\mathrm{R} 2$ & \\
\hline $\begin{array}{c}0.0 \\
\text { (Control) }\end{array}$ & $724.00 \pm 23.69$ & $692.92 \pm 6.09$ & $708.46^{\mathrm{A}} \pm 12.39$ \\
\hline 0.2 & $490.42 \pm 16.61$ & $382.00 \pm 5.95$ & $436.21^{\mathrm{BC}} \pm 14.22$ \\
\hline 0.4 & $550.75 \pm 8.14$ & $429.92 \pm 3.36$ & $490.33^{\mathrm{B}} \pm 13.31$ \\
\hline 0.6 & $473.00 \pm 37.32$ & $417.42 \pm 38.84$ & $445.21^{\mathrm{BC}} \pm 26.97$ \\
\hline 0.8 & $461.50 \pm 10.58$ & $393.75 \pm 12.88$ & $427.63^{\mathrm{C}} \pm 10.78$ \\
\hline 10.0 & $438.00 \pm 17.41$ & $373.75 \pm 13.53$ & $405.88^{\mathrm{C}} \pm 12.69$ \\
\hline $\begin{array}{c}\text { Diet-type } \\
\text { overall }\end{array}$ & $522.94^{\mathrm{A}} \pm 8.04$ & $448.29^{\mathrm{B}} \pm 8.04$ & \\
\hline HSD & \multicolumn{2}{|c|}{22.493} & 56.95 \\
\hline $\begin{array}{l}\text { HSD of } \\
\text { interaction }\end{array}$ & \multicolumn{2}{|c|}{92.685} & \\
\hline
\end{tabular}

$\mathrm{R} 1=70 \%$ forage: $30 \%$ concentrates; $\mathrm{R} 2=60 \%$ forage: $40 \%$ concentrates; Means with different superscripts are significantly different $(p \leq 0.05)$.

[30], 12\% [34]. The conflicted effects of essential oils may be related to the different species of eucalyptus [30].

Eucalyptus oil plays a crucial role in $\mathrm{CH}_{4}$ depression as a result to its highly desaturation point, which causes toxicity for methanogens bacteria [35]. The eucalyptus oil showed a mitigation ability to suppress the production of $\mathrm{CH}_{4}$. Generally, EuO can reduce methane production in a dramatic way. In addition, a higher percentage of roughage-to-concentrate had a significant effect on decreasing the methane concentrations. Similar to the current study, Soltan, et al. [36] found that Moringa oleifera root decreased the levels of $\mathrm{CH}_{4}$ without any effect on the total gas production level.

Sallam, et al. [14] found that different levels of eucalyptus oil have a linear reduction in methane production. This result was not similar to our result. Eucalyptus decreased methane production in an interaction with the two diets in a non-linear effect, while Nooriyan and Rouzbehan [37] found that the effect of adding Eucalyptus oil on methane was nonlinear. The lower level of methane production in the higher $\mathrm{CP}$ diet than the fibrous diet has been reported under in vitro conditions in some fatty acids (mysteric acid) [38] and different algae [39, 40]. This was in contrast with O'Brien, et al. [41], who found that some other fatty acids (lauric, oleic, linoleic, and linolenic) contributed to increasing methane production when they were incubated with low levels of $\mathrm{CP}$ and then a high-level CP diet. In the herein study, ration 2 had a higher $\mathrm{CP}$ content $(8.72 \%)$ than ration $1(7.34 \%)$, which could have relatively contributed to the obtained results. 
Table 4. Effects of different levels of eucalyptus oil on $\mathrm{pH}$ value under different types of rations.

\begin{tabular}{|c|c|c|c|}
\hline Item & \multicolumn{2}{|c|}{ Diet } & \multirow{2}{*}{$\begin{array}{c}\text { Oil-level } \\
\text { overall }\end{array}$} \\
\hline Oil level (mL) & $\mathrm{R} 1$ & $\mathrm{R} 2$ & \\
\hline 0.0 (Control) & $6.31 \pm 0.04$ & $6.19 \pm 0.06$ & $6.25 \pm 0.04$ \\
\hline 0.2 & $6.30 \pm 0.04$ & $6.14 \pm 0.04$ & $6.22 \pm 0.03$ \\
\hline 0.4 & $6.32 \pm 0.04$ & $6.11 \pm 0.04$ & $6.21 \pm 0.03$ \\
\hline 0.6 & $6.30 \pm 0.04$ & $6.10 \pm 0.04$ & $6.20 \pm 0.03$ \\
\hline 0.8 & $6.29 \pm 0.04$ & $6.12 \pm 0.04$ & $6.21 \pm 0.03$ \\
\hline 10.0 & $6.23 \pm 0.05$ & $6.23 \pm 0.07$ & $6.12 \pm 0.04$ \\
\hline Diet-type overall & $6.29^{\mathrm{A}} \pm 0.02$ & $6.11^{\mathrm{B}} \pm 0.02$ & \\
\hline HSD & \multicolumn{2}{|c|}{0.0579} & 0.1467 \\
\hline $\begin{array}{l}\text { HSD of } \\
\text { interaction }\end{array}$ & \multicolumn{2}{|c|}{0.2387} & \\
\hline
\end{tabular}

$\mathrm{R} 1=70 \%$ forage: $30 \%$ concentrates; $\mathrm{R} 2=60 \%$ forage: $40 \%$ concentrates; Means with different superscripts are significantly different $(p \leq 0.05)$.

\section{$\mathrm{pH}$ and $\mathrm{NH}_{3}$}

The diet-type overall of R1 was significantly higher in the $\mathrm{pH}$ value compared with $\mathrm{R} 2(\mathrm{~F}=39.25 ; p<0.0001)$. Regardless of the diet type, the highest oil-level overall of the $\mathrm{pH}$ level was observed in the control group while the lowest level was observed at the concentration of $10 \mathrm{~mL} \mathrm{EuO} \mathrm{with} \mathrm{no} \mathrm{significant} \mathrm{difference} \mathrm{between} \mathrm{the}$ levels of the oil $(\mathrm{F}=1.46 ; p=0.2076)$. The higher level of $\mathrm{pH}$ was observed in control group at $\mathrm{R} 1$ while the lower level was observed in $\mathrm{R} 2$ at the level of $10.0 \mathrm{~mL}$ EUO, and there were no significant differences between these groups $(\mathrm{F}=0.27 ; p=0.9271)$ (Table 4$)$.

The diet-type overall of $\mathrm{NH}_{3}$ between $\mathrm{R} 1$ and $\mathrm{R} 2$ had no significant difference $(\mathrm{F}=0.78 ; p=0.3776)$. Regardless of the diet type, the highest overall of $\mathrm{NH}_{3}$ was observed at the oil level of $0.4 \mathrm{~mL}$, while the lower level was observed in the level of $10 \mathrm{~mL}$ Euo $(\mathrm{F}=17.22 ; p<0.0001) . \mathrm{NH}_{3}$ had an interaction between the diet and the oil levels ( $\mathrm{F}=13.60 ; p<0.0001)$, since the higher levels of $\mathrm{NH}_{3}$ were observed in the levels of $0.4 \mathrm{~mL}$, while the lower levels were observed in the level of $10 \mathrm{~mL}$ of Euo for R1 (Table 5). In this regard, Klevenhusen, et al. [42] and Khorrami, et al. [43] found that EO did not affect ruminal ammonia. Tomkins, et al. [44] did not find any significance between control and adding a blend of essential oils on $\mathrm{NH}_{3}$. Sharifi, et al. [45] found that grape seed oil had no effect on the ammonia level of lambs. It was suggested that essential oils can decrease the concentration of ammonia in the rumen by inhibiting protein and peptide degradation [46]. Many studies found that the dose of essential oils that inhibits methane is higher than the dose that inhibits ammonia production [30, 34, 47, 48]. Also, this result was matched to [49] using Rosmarinus officinalis.
Table 5. Effects of different levels of eucalyptus oil on ammonia concentration (mmol) under different types of rations.

\begin{tabular}{|c|c|c|c|}
\hline Item & \multicolumn{2}{|c|}{ Diet } & \multirow{2}{*}{$\begin{array}{c}\text { Oil-level } \\
\text { overall }\end{array}$} \\
\hline $\begin{array}{l}\text { Oil level } \\
(\mathrm{mL})\end{array}$ & $\mathrm{R} 1$ & $\mathrm{R} 2$ & \\
\hline $\begin{array}{c}0.0 \\
\text { (Control) }\end{array}$ & $246.02^{\mathrm{AB}} \pm 2.28$ & $243.6^{\mathrm{ABC}_{ \pm}} 1.78$ & $244.83^{\mathrm{AB}} \pm 1.43$ \\
\hline 0.2 & $241.01^{\mathrm{BC}} \pm 3.80$ & $234.75^{\mathrm{BC}} \pm 2.40$ & $237.87^{\mathrm{BC}} \pm 2.29$ \\
\hline 0.4 & $256.03^{\mathrm{A}} \pm 4.15$ & $238.83^{\mathrm{BC}} \pm 2.22$ & $247.41^{\mathrm{A}} \pm 2.91$ \\
\hline 0.6 & $240.58^{\mathrm{BC}} \pm 1.90$ & $242.58^{\mathrm{BC}} \pm 3.74$ & $241.58^{\mathrm{ABC}_{ \pm}} \pm 2.06$ \\
\hline 0.8 & $232.50^{\mathrm{C}} \pm 2.36$ & $239.75^{\mathrm{BC}} \pm 2.05$ & $236.16^{\mathrm{C}} \pm 1.70$ \\
\hline 10.0 & $212.51^{\mathrm{D}} \pm 1.94$ & $237.41^{\mathrm{BC}_{ \pm}} \pm 2.54$ & $224.95^{\mathrm{D}} \pm 3.03$ \\
\hline $\begin{array}{c}\text { Diet-type } \\
\text { overall }\end{array}$ & $238.11^{\mathrm{A}} \pm 1.10$ & $239.50^{\mathrm{A}} \pm 1.10$ & \\
\hline HSD & \multicolumn{2}{|c|}{3.103} & 7.8577 \\
\hline $\begin{array}{l}\text { HSD of } \\
\text { interaction }\end{array}$ & \multicolumn{2}{|c|}{12.78} & \\
\hline
\end{tabular}

$\mathrm{R} 1=70 \%$ forage: $30 \%$ concentrates; $\mathrm{R} 2=60 \%$ forage: $40 \%$ concentrates; Means with different superscriptss are significantly different $(p \leq 0.05)$.

The ruminal $\mathrm{pH}$ can be decreased by a starch-rich diet leading to low digestibility [50], and enhanced synthesis of propionic acid, while roughage-based diets can enhance the synthesis of acetic acid [51]. The insignificant $\mathrm{pH}$ value may refer to the normality of the ruminal culture that reflects on feed degradability, which represents an advantage to adding the oil. In the same regard, essential oils did not affect $\mathrm{pH}$ under in vivo conditions [42, 52, 53]. McIntosh, et al. [12], and Patra and $\mathrm{Yu}$ [34] investigated the essential oil of oregano and clover that led to a decrease of the ammonia concentrations compared with both garlic and eucalyptus oil under in vitro conditions.

Although $\mathrm{EuO}$ inclusion did not exhibit clear patterns on $\mathrm{pH}$ or fermentation viability, it showed $\mathrm{NH}_{3}-\mathrm{N}$ interaction with $\mathrm{T} 6$ of ration 2 production, suggesting that with the increase both of concentrate and the VFA, the accumulated $\mathrm{H}$ could be changed into $\mathrm{NH}_{3}$ formation instead of $\mathrm{CH}_{4}$ pathway [54].

\section{VFA and Acetic to Propionic Ratio}

The volatile fatty acids are mainly synthesized by the rumin microbial fermentation for the dietary organic matter. Such volatile fatty acids represent energy source precursors for the main biological metabolites, such as propionic acid, that form glycogen, butyric acid, longer-chain fatty acids; and acetic acid, short- and medium-chain fatty acids [55]. The quantity, quality, and fermentation pace of dietary fibers affect both the total and proportions production of individual VFAs synthesized and, finally, the amount of methanogenesis. 
Table 6. Effects of different levels of eucalyptus oil on acetic acid $(\mathrm{mol} / 100 \mathrm{~mol})$ and acetic-to-propionic ratio under two types of rations.

\begin{tabular}{|c|c|c|c|}
\hline Item & \multicolumn{2}{|c|}{ Diet } & \multirow{2}{*}{$\begin{array}{c}\text { Oil-level } \\
\text { overall }\end{array}$} \\
\hline $\begin{array}{l}\text { Oil level } \\
(\mathrm{mL})\end{array}$ & $\mathrm{R} 1$ & $\mathrm{R} 2$ & \\
\hline 0.0 (Control) & $53.02^{\mathrm{BC}_{ \pm}} 0.41$ & $50.96^{\mathrm{DE}} \pm 0.37$ & $51.99^{\mathrm{AB}} \pm 0.34$ \\
\hline 0.2 & $51.29^{\mathrm{CDE}} \pm 0.54$ & $50.73^{\mathrm{E}} \pm 0.38$ & $51.01^{\mathrm{B}} \pm 0.33$ \\
\hline 0.4 & $52.89^{\mathrm{BCD}} \pm 0.50$ & $51.31^{\mathrm{CDE}} \pm 0.38$ & $52.10^{\mathrm{AB}} \pm 0.35$ \\
\hline 0.6 & $53.72^{\mathrm{AB}} \pm 0.44$ & $51.30^{\mathrm{CDE}} \pm 0.38$ & $52.51^{\mathrm{A}} \pm 0.38$ \\
\hline 0.8 & $53.99^{\mathrm{AB}} \pm 0.45$ & $51.29^{\mathrm{CDE}} \pm 0.38$ & $52.64^{\mathrm{A}} \pm 0.40$ \\
\hline 10.0 & $55.23^{\mathrm{A}} \pm 0.50$ & $51.12^{\mathrm{CDE}} \pm 0.37$ & $53.17^{\mathrm{A}} \pm 0.52$ \\
\hline $\begin{array}{c}\text { Diet-type } \\
\text { overall }\end{array}$ & $53.35^{\mathrm{A}} \pm 0.17$ & $51.12^{\mathrm{B}} \pm 0.17$ & \\
\hline HSD & \multicolumn{2}{|c|}{0.496} & 1.2559 \\
\hline $\begin{array}{l}\text { HSD of } \\
\text { interaction }\end{array}$ & \multicolumn{2}{|c|}{2.0437} & \\
\hline
\end{tabular}

$\mathrm{R} 1=70 \%$ forage: $30 \%$ concentrates; $\mathrm{R} 2=60 \%$ forage: $40 \%$ concentrates; Means with different superscripts are significantly different $(p \leq 0.05)$.

The diet-type overall of acetic acid was significantly higher in R1 than in R2 ( $\mathrm{F}=79.54 ; p<0.0001)$. The highest oil-level overall was observed at the level of $10 \mathrm{~mL}$, while the lowest level was observed at $2.0 \mathrm{~mL}$ Euo $(\mathrm{F}=05.74 ; p<0.0001)$. The acetic acid had an interaction between the diet and the oil levels $(\mathrm{F}=3.73 ; p=0.003)$, since the higher levels of acetic acid were observed in the levels of $10.0 \mathrm{~mL} \mathrm{EuO} \mathrm{in}$

Table 7. Effects of different levels of eucalyptus oil on propionic acid $(\mathrm{mol} / 100 \mathrm{~mol})$ under two types of rations.

\begin{tabular}{|c|c|c|c|}
\hline Item & \multicolumn{2}{|c|}{ Diet } & \multirow{2}{*}{$\begin{array}{c}\text { Oil-level } \\
\text { overall }\end{array}$} \\
\hline $\begin{array}{l}\text { Oil level } \\
(\mathrm{mL})\end{array}$ & $\mathrm{R} 1$ & $\mathrm{R} 2$ & \\
\hline 0.0 (Control) & $13.3567^{\mathrm{F}} \pm 0.11$ & $13.82^{\mathrm{DEF}} \pm 0.10$ & $13.59^{\mathrm{C}} \pm 0.09$ \\
\hline 0.2 & $13.56^{\mathrm{EF}} \pm 0.27$ & $13.96^{\mathrm{CDEF}} \pm 0.10$ & $13.76^{\mathrm{C}} \pm 0.14$ \\
\hline 0.4 & $14.34^{\mathrm{BC}} \pm 0.15$ & $14.13^{\mathrm{CDE}} \pm 0.11$ & $14.23^{\mathrm{B}} \pm 0.09$ \\
\hline 0.6 & $14.57^{\mathrm{BC}} \pm 0.11$ & $14.13^{\mathrm{CDE}} \pm 0.10$ & $14.35^{\mathrm{B}} \pm 0.08$ \\
\hline 0.8 & $14.81^{\mathrm{AB}_{ \pm}} \pm 0.11$ & $14.18^{\mathrm{BCDE}} \pm 0.13$ & $14.49^{\mathrm{AB}} \pm 0.10$ \\
\hline 10.0 & $15.4^{\mathrm{A}} \pm 0.12$ & $14.25^{\mathrm{BCD}} \pm 0.10$ & $14.84^{\mathrm{A}} \pm 0.14$ \\
\hline $\begin{array}{c}\text { Diet-type } \\
\text { overall }\end{array}$ & $14.34^{\mathrm{A}} \pm 14.34$ & $14.08^{\mathrm{B}} \pm 14.34$ & \\
\hline HSD & \multicolumn{2}{|c|}{0.158} & 0.4001 \\
\hline $\begin{array}{l}\text { HSD of } \\
\text { interaction }\end{array}$ & \multicolumn{2}{|c|}{0.6511} & \\
\hline
\end{tabular}

$\mathrm{R} 1=70 \%$ forage: $30 \%$ concentrates; $\mathrm{R} 2=60 \%$ forage: $40 \%$ concentrates; Means with different superscripts are significantly different $(p \leq 0.05)$
Table 8. Effects of different levels of eucalyptus oil on butyric acid $(\mathrm{mol} / 100 \mathrm{~mol})$ under two types of rations.

\begin{tabular}{|c|c|c|c|}
\hline Item & \multicolumn{2}{|c|}{ Diet } & \multirow{2}{*}{$\begin{array}{c}\text { Oil-level } \\
\text { overall }\end{array}$} \\
\hline Oil level (mL) & R1 & R2 & \\
\hline 0.0 (Control) & $6.68^{\mathrm{B}} \pm 0.07$ & $5.98^{\mathrm{C}} \pm 0.05$ & $6.33^{\mathrm{B}} \pm 0.08$ \\
\hline 0.2 & $6.94^{\mathrm{AB}} \pm 0.05$ & $6.08^{\mathrm{C}} \pm 0.04$ & $6.51^{\mathrm{AB}} \pm 0.09$ \\
\hline 0.4 & $6.61^{\mathrm{B}} \pm 0.17$ & $6.13^{\mathrm{C}_{ \pm}} \pm 0.04$ & $6.37^{\mathrm{AB}} \pm 0.10$ \\
\hline 0.6 & $7.05^{\mathrm{A}} \pm 0.05$ & $6.12^{\mathrm{C}} \pm 0.04$ & $6.59^{\mathrm{A}} \pm 0.10$ \\
\hline 0.8 & $6.08 \pm 0.08$ & $6.13^{\mathrm{C}} \pm 0.04$ & $6.11^{\mathrm{C}} \pm 0.04$ \\
\hline 10.0 & $5.78^{\mathrm{C}} \pm 0.05$ & $6.07^{\mathrm{C}} \pm 0.05$ & $5.93^{\mathrm{C}} \pm 0.04$ \\
\hline $\begin{array}{c}\text { Diet-type } \\
\text { overall }\end{array}$ & $6.53^{\mathrm{A}} \pm 0.03$ & $6.09^{\mathrm{B}} \pm 0.03$ & \\
\hline HSD & \multicolumn{2}{|c|}{0.0861} & 0.218 \\
\hline $\begin{array}{l}\text { HSD of } \\
\text { interaction }\end{array}$ & \multicolumn{2}{|c|}{0.3547} & \\
\hline
\end{tabular}

$\mathrm{R} 1=70 \%$ forage: $30 \%$ concentrates; $\mathrm{R} 2=60 \%$ forage: $40 \%$ concentrates; Means with different superscripts are significantly different $(p \leq 0.05)$.

$\mathrm{R} 1$, while the lower level was observed in the level of $2.0 \mathrm{~mL}$ Euo in R2 (Table 6).

The diet-type overall of propionic acid was significantly higher in $\mathrm{R} 1$ than in $\mathrm{R} 2(\mathrm{~F}=10.80$; $p=0.0013)$. The highest oil-level overall was significantly observed at the level of $10 \mathrm{~mL}$ Euo, while the lowest was observed at the control level $(\mathrm{F}=05.74$; $p<0$. 0001). Propionic acid had an interaction between the diet and the oil levels $(\mathrm{F}=10.39 ; p<0.0001)$, since the higher level of propionic acid was observed in R1 at the level of $10 \mathrm{~mL} \mathrm{EuO} \mathrm{while} \mathrm{the} \mathrm{lower} \mathrm{level} \mathrm{was}$ observed in the control group of R1 (Table 7).

The diet-type overall of butyric acid was significantly higher in $\mathrm{R} 1$ than in $\mathrm{R} 2(\mathrm{~F}=101.70$; $p<0.0001)$. Regardless of diet type, the overall oil level was significantly higher at the level of $6.0 \mathrm{~mL}$ $\mathrm{EuO}$ and was lower at the level of $8.0 \mathrm{~mL}(\mathrm{~F}=21.85$; $p<0.0001)$. A similar trend was observed within different treatments of $\mathrm{R} 1$, since the butyric acid had an interaction between the diet and the oil levels $(\mathrm{F}=22.21 ; p<0.0001)$ (Table 8$)$.

The diet-type overall of R1 was significantly higher than in $\mathrm{R} 2$. $(\mathrm{F}=25.59 ; p<0.0001)$. The oil-level overall was significantly increased in a dose-dependent manner $(\mathrm{F}=13.25 ; p<0.0001)$. A similar trend was observed in the acetic-to-propionic (A/P) ratio, since $\mathrm{A} / \mathrm{P}$ had an interaction between the diet type and the oil level. $\mathrm{A} / \mathrm{P}$ was significantly higher in both diets at the control level and significantly lower at $10.0 \mathrm{~mL} \mathrm{EuO}(\mathrm{F}=5.36$; $p=0.0002$ ) (Table 9).

Our results are in agreement with Tatsuoka, et al. [33], who stated that acetic, butyric, and propionic did not exhibit a clear direction in acetic acid using different types of EuO in comparison with the control, whereas Kouazounde, et al. [19] found that acetic and butyric acid 
Table 9. Effects of different levels of eucalyptus oil on acetic-topropionic ratio under two types of rations.

\begin{tabular}{|c|c|c|c|}
\hline Item & \multicolumn{2}{|c|}{ Diet } & \multirow{2}{*}{$\begin{array}{c}\text { Oil-level } \\
\text { overall }\end{array}$} \\
\hline Oil level (mL) & R1 & R2 & \\
\hline 0.0 (Control) & $3.97^{\mathrm{A}} \pm 0.03$ & $3.68^{\mathrm{C}} \pm 0.02$ & $3.82^{\mathrm{A}} \pm 0.03$ \\
\hline 0.2 & $3.79^{\mathrm{B}} \pm 0.05$ & $3.63^{\mathrm{CD}} \pm 0.02$ & $3.71^{\mathrm{B}} \pm 0.03$ \\
\hline 0.4 & $3.68^{\mathrm{BC}} \pm 0.03$ & $3.63^{\mathrm{CD}} \pm 0.02$ & $3.65^{\mathrm{BC}} \pm 0.02$ \\
\hline 0.6 & $3.68^{\mathrm{CB}_{ \pm}} \pm 0.02$ & $3.63^{\mathrm{CD}} \pm 0.02$ & $3.66^{\mathrm{BC}} \pm 0.02$ \\
\hline 0.8 & $3.64^{\mathrm{BC}} \pm 0.03$ & $3.61^{\mathrm{CD}} \pm 0.03$ & $3.63^{\mathrm{BC}} \pm 0.02$ \\
\hline 10.0 & $3.57^{\mathrm{C}} \pm 0.02$ & $3.58^{\mathrm{D}} \pm 0.02$ & $3.58^{\mathrm{C}} \pm 0.01$ \\
\hline Diet-type overall & $3.72^{\mathrm{A}} \pm 0.01$ & $3.63^{\mathrm{B}} \pm 0.01$ & \\
\hline HSD & \multicolumn{2}{|c|}{0.0376} & 0.0952 \\
\hline $\begin{array}{l}\text { HSD of } \\
\text { interaction }\end{array}$ & \multicolumn{2}{|c|}{0.0921} & \\
\hline
\end{tabular}

$\mathrm{R} 1=70 \%$ forage: $30 \%$ concentrates; $\mathrm{R} 2=60 \%$ forage:

$40 \%$ concentrates; Means with different superscripts are significantly different $(p \leq 0.05)$.

concentrations were increased dramatically compared with the control, while propionic acid concentrations were lower than the control. Yet Cobellis, et al. [30] found that acetic and propionic acid concentrations were lower in EuO-treated group compared with the control, otherwise, butyric acid concentration was lower in comparison with the control. In contrast, acetic was decreased by adding essential oils in a feedlot in an in vivo study [53], and dairy cows [56].

The concentrations of VFA were investigated in several studies and showed a slight effect with low doses, while VFA concentration showed a significant effect with high doses of essential oils [30, 46]. Various studies showed absolutely positive changes accompanied by methane restraint. In the study of Patra and Saxena [57], they found that the inhibition of methane was correlated with increasing propionate and decreased the acetic-to-propionic ratio. On the other hand, Cobellis, et al. [30] stated that there are some other causes and some other factors that can influence the VFA concentrations as the substrate type and the medium conditions. In contrast with these results, the VFA concentrations were decreased by the inclusion of $\mathrm{EuO}$ at $0.66,1.0$, 1.33, and $1.66 \mu \mathrm{L} / \mathrm{mL}$ [17]. Furthermore, Thao, et al. [58] stated that daily $2 \mathrm{~mL}$ of EUO administered to swamp buffaloes lowered the proportions of acetate and acetate-to-propionate ratio but increased the propionate proportion.

However, in the study of Maia, et al. [39], the effects on methane and total VFA production depended on the substrate used.

Acetic acid ratio was decreased and total VFA production and the propionic acid ratio were increased when 5\% sunflower oil supplemented the cow diet. Acetic acid and butyric acid increase methanogenesis,
Table 10. Effects of different levels of eucalyptus oil on dry matter degradation (g.kg-1 DM) under different types of rations.

\begin{tabular}{|c|c|c|c|}
\hline Item & \multicolumn{2}{|c|}{ Diet } & \multirow{2}{*}{$\begin{array}{c}\text { Oil-level } \\
\text { overall }\end{array}$} \\
\hline $\begin{array}{l}\text { Oil level } \\
(\mathrm{mL})\end{array}$ & $\mathrm{R} 1$ & $\mathrm{R} 2$ & \\
\hline 0.0 (Control) & $600.5^{\mathrm{A}} \pm 4.99$ & $563.0^{\mathrm{AB}} \pm 10.830$ & $581.7^{\mathrm{A}} \pm 7.02$ \\
\hline 0.2 & $569.0^{\mathrm{AB}} \pm 5.35$ & $519.0^{\mathrm{B}} \pm 29.47$ & $544.0^{\mathrm{B}} \pm 15.54$ \\
\hline 0.4 & $535.2^{\mathrm{B}} \pm 5.93$ & $535.2^{\mathrm{B}} \pm 15.08$ & $537.7^{\mathrm{B}} \pm 7.94$ \\
\hline 0.6 & $548.7^{\mathrm{AB}} \pm 4.89$ & $540.25^{\mathrm{B}} \pm 5.93$ & $492.0^{\mathrm{C}} \pm 12.41$ \\
\hline 0.8 & $541.2^{\mathrm{B}} \pm 4.35$ & $425.88^{\mathrm{C}} \pm 15.72$ & $483.5^{\mathrm{C}} \pm 14.43$ \\
\hline 10.0 & $543.5^{\mathrm{AB}} \pm 6.03$ & $421.1^{C} \pm 10.21$ & $482.3^{\mathrm{C}} \pm 14.01$ \\
\hline $\begin{array}{c}\text { Diet-type } \\
\text { overall }\end{array}$ & $556.37^{\mathrm{A}} \pm 4.95$ & $484.09^{\mathrm{B}} \pm 4.95$ & \\
\hline HSD & \multicolumn{2}{|c|}{13.865} & 35.111 \\
\hline $\begin{array}{l}\text { HSD of } \\
\text { interaction }\end{array}$ & \multicolumn{2}{|c|}{57.133} & \\
\hline
\end{tabular}

$\mathrm{R} 1=70 \%$ forage: $30 \%$ concentrates; $\mathrm{R} 2=60 \%$ forage: $40 \%$ concentrates; Means with different superscripts are significantly different $(p \leq 0.05)$.

whereas synthesis of propionic acid production can be considered an alternative pathway for hydrogen ion accumulation in the rumen [59]. It was found by Pawar, et al. [60], that acetic acid was increased by adding essential oils.

Fatty acids have a crucial inhibitory role on protozoa and cellulolytic bacteria [61]. The reduction in methanogenesis led to altering fermentation into propionic acid synthesis [62]. Methane-producing bacteria are the basic users of hydrogen ions in the rumen. Natural feed additives such as essential oils can be considered useful in ruminant nutrition when they determine an increase of total VFA and propionic acid production and a decrease of the acetic/propionic acid ratio [63]. The reduction of methane formation can lead to the accumulation of excess declining equivalents that can enhance intracellular NADH/NAD, thus inhibiting total fermentation efficiency by limiting the accessibility of oxidized cofactors demanded for glycolysis [64], or leading to an enhanced in propionic acid or $\mathrm{NH}_{3}-\mathrm{N}$ synthesis [54].

\section{Feed Degradation}

The diet-type overall of DMD was significantly higher in R1 than in R2 $(\mathrm{F}=106.34 ; p<0.0001)$. The oil-level overall was significantly higher in all oil treatments than in control group in a dose-dependent manner $(\mathrm{F}=22.35 ; p<0.0001)$. The DMD levels had an interaction effect between the diet type and the oil level $(\mathrm{F}=9.32 ; p<0.0001)$, since the higher level of DMD was observed at the control level of R1 while the lowest level was observed in the level of $10 \mathrm{~mL} \mathrm{EuO} \mathrm{of} \mathrm{R2}$ $(\mathrm{F}=9.32 ; p<0.0001)($ Table 10$)$. 
Table 11. Effects of different levels of eucalyptus oil on organic matter degradation (g.kg ${ }^{-1} \mathrm{DM}$ ) under different types of rations.

\begin{tabular}{|c|c|c|c|}
\hline Item & \multicolumn{2}{|c|}{ Diet } & \multirow{2}{*}{$\begin{array}{c}\text { Oil-level } \\
\text { overall }\end{array}$} \\
\hline $\begin{array}{l}\text { Oil level } \\
(\mathrm{mL})\end{array}$ & R1 & R2 & \\
\hline $\begin{array}{c}0.0 \\
\text { (Control) }\end{array}$ & $462.42 \pm 12.60$ & $412.50 \pm 12.547$ & $437.47^{\mathrm{AB}} \pm 10.13$ \\
\hline 0.2 & $473.33 \pm 8.16$ & $423.42 \pm 8.00$ & $448.37^{\mathrm{A}} \pm 7.63$ \\
\hline 0.4 & $458.3 \pm 4.01$ & $408.42 \pm 3.63$ & $433.37^{\mathrm{AB}} \pm 5.83$ \\
\hline 0.6 & $455.2 \pm 8.30$ & $413.58 \pm 3.85$ & $434.41^{\mathrm{AB}} \pm 6.23$ \\
\hline 0.8 & $428.33 \pm 3.47$ & $405.25 \pm 8.24$ & $416.79^{\mathrm{B}} \pm 4.99$ \\
\hline 10.0 & $451.17 \pm 5.20$ & $400.9 \pm 6.64$ & $426.04^{\mathrm{B}} \pm 6.66$ \\
\hline $\begin{array}{c}\text { Diet-type } \\
\text { overall }\end{array}$ & $454.80^{\mathrm{A}} \pm 3.14$ & $410.68^{\mathrm{B}} \pm 3.14$ & \\
\hline HSD & \multicolumn{2}{|c|}{8.7942} & 22.27 \\
\hline $\begin{array}{l}\text { HSD of } \\
\text { interaction }\end{array}$ & \multicolumn{2}{|c|}{36.237} & \\
\hline
\end{tabular}

$\mathrm{R} 1=70 \%$ forage: $30 \%$ concentrates; $\mathrm{R} 2=60 \%$ forage: $40 \%$ concentrates; Means with different superscripts are significantly different $(p \leq 0.05)$

The diet-type overall of OMD was significantly higher in $\mathrm{R} 1$ than in $\mathrm{R} 2(\mathrm{~F}=98.51 ; p<0.0001)$. The oil-level overall was significantly lower in the level of $10 \mathrm{~mL}$ Euo while the higher level was observed at the levels of control and $2.0 \mathrm{~mL}$ of $\mathrm{EuO}(\mathrm{F}=22.35$; $p<0.0001)$. The DMD levels had an interaction effect between the diet type and the oil level $(\mathrm{F}=9.32$; $p=0.0028$.). No interaction effect was detected between the diet type and the oil level on OMD $(\mathrm{F}=9.32 ; p<0.0001)($ Table 11$)$.

The diet-type overall of partitioning factor (PF) value was significantly higher in R1 than in R2 $(\mathrm{F}=46.81 ; p<0.0001)$. In addition, the oil-level overall of $\mathrm{PF}$ was significantly higher at the control level, whereas the lower control level was observed at the level of $10.0 \mathrm{~mL} \mathrm{EuO} \mathrm{(F=3.02;} p<0.0128)$. No interaction effect was detected between diet type and the oil level on PF $(\mathrm{F}=0.89 ; p=0.4887)$ (Table 12).

Regardig PF, there was no significant difference in both rations and there was a slight decrease in comparison with the control, and no interaction was detected between the evaluated main effects. In this regard, Pawar, et al. [60] found that adding clove oil has no effect on PF value.

The approaches of reducing methane should not negatively affect digestibility, the use of additives that decrease feed digestion, and cannot be a good mitigation strategy [65]. Panthee, et al. [66] found that adding garlic leaves improved digestibility in sheep, since the mechanism of mitigation should depend on changing the hydrogen pathway or inhibit the microflora. The current results provide these points. The inhibition in methane was correlated with inhibition in protozoa, and
Table 12. Effects of different levels of eucalyptus oil on partitioning factor $(\mathrm{mL} / \mathrm{L})$ under different types of rations.

\begin{tabular}{|c|c|c|c|}
\hline Item & \multicolumn{2}{|c|}{ Diet } & \multirow{2}{*}{$\begin{array}{c}\text { Oil-level } \\
\text { overall }\end{array}$} \\
\hline $\begin{array}{l}\text { Oil level } \\
(\mathrm{mL})\end{array}$ & $\mathrm{R} 1$ & $\mathrm{R} 2$ & \\
\hline 0.0 (Control) & $4.76 \pm 0.12$ & $4.44 \pm 0.13$ & $4.60^{\mathrm{AB}} \pm 0.09$ \\
\hline 0.2 & $4.96 \pm 0.08$ & $4.57 \pm 0.08$ & $4.77^{\mathrm{A}} \pm 0.07$ \\
\hline 0.4 & $4.79 \pm 0.04$ & $4.41 \pm 0.04$ & $4.60^{\mathrm{AB}} \pm 0.05$ \\
\hline 0.6 & $4.78 \pm 0.09$ & $4.47 \pm 0.04$ & $4.63^{\mathrm{AB}} \pm 0.05$ \\
\hline 0.8 & $4.51 \pm 0.04$ & $4.39 \pm 0.09$ & $4.45^{\mathrm{B}} \pm 0.05$ \\
\hline 10.0 & $4.79 \pm 0.04$ & $4.37 \pm 0.07$ & $4.58^{\mathrm{AB}} \pm 0.06$ \\
\hline $\begin{array}{c}\text { Diet-type } \\
\text { overall }\end{array}$ & $4.77^{\mathrm{A}} \pm 0.03$ & $4.44^{\mathrm{B}} \pm 0.03$ & \\
\hline HSD & \multicolumn{2}{|c|}{0.0942} & 0.2385 \\
\hline $\begin{array}{l}\text { HSD of } \\
\text { interaction }\end{array}$ & \multicolumn{2}{|c|}{0.388} & \\
\hline
\end{tabular}

$\mathrm{R} 1=70 \%$ forage: $30 \%$ concentrates; $\mathrm{R} 2=60 \%$ forage: $40 \%$ concentrates; Means with different superscripts are significantly different $(p \leq 0.05)$.

was in parallel with $\mathrm{A} / \mathrm{P}$ decline, without impairing the DMD, and OMD as manifested by Sejian, et al. [67]. In this regard, the effect of adding eucalyptus oil was different on DMD compared to OMD. The relationship between OMD and DMD was also inconsistent in many other studies [68-70]. Roy, et al. [32] stated that Euo improved the value of OMD. Such improvement was related with a low level of oils and lower level of methane production, as reported in the current study.

\section{Protozoal Count}

The diet-type overall of protozoal count was significantly higher in $\mathrm{R} 2$ than in $\mathrm{R} 1 \quad(\mathrm{~F}=49.93$; $p<0.0001)$. Regarding the oil level overall, the protozoal count was significantly higher at the control level, whereas the lower control level was observed at the level of $10.0 \mathrm{~mL} \mathrm{EuO}(\mathrm{F}=39.57 ; p<0.0001)$. Similar trends were observed in both R1 and R2 treatments, since the protozoal count had an interaction between the diet and the oil levels on the protozoal count $(\mathrm{F}=7.45 ; p<0.0001)$ (Table 13).

Similar to the results of R1, Hristov, et al. [71] found no effects of $\mathrm{EuO}$ on microbial fermentation when EUO was supplemented to rumen cultures at 10 and $100 \mathrm{mg} / \mathrm{L}$. Conversely, it has been confirmed that there is a contribution of protozoa on methane production, which reaches $37 \%$ in the study of Hegarty, et al. [72]. Flavonoids and tannins pose a part of the $\mathrm{EuO}$ constituents, which are able to constrain the rumen bioactivities for methanogens and protozoa, and which reflect its ability to suppress methane production [14, 73]. Protozoal repression concurrently with methane 
Table 13. Effects of different levels of eucalyptus oil on protozoal count under different types of rations.

\begin{tabular}{|c|c|c|c|}
\hline Item & \multicolumn{2}{|c|}{ Diet } & \multirow{2}{*}{ Oil-level overall } \\
\hline Oil level (mL) & R1 & $\mathrm{R} 2$ & \\
\hline 0.0 (Control) & $1710.32^{\mathrm{BC}_{ \pm}} 88.50$ & $2109.5^{\mathrm{A}} \pm 16.6$ & $1909.92^{\mathrm{A}} \pm 60.60$ \\
\hline 0.2 & $1133.81^{\mathrm{DEFG}_{ \pm} 97.05}$ & $1891.4^{\mathrm{AB}} \pm 38.2$ & $1512.58^{\mathrm{B}} \pm 94.03$ \\
\hline 0.4 & $1485.04^{\mathrm{CD}_{ \pm}}+190.38$ & $2011.0^{\mathrm{AB}} \pm 20.96$ & $1748.00^{\mathrm{AB}} \pm 108.53$ \\
\hline 0.6 & $1437.33^{\mathrm{CDE}} \pm 147.68$ & $1821.9^{\mathrm{ABC}_{ \pm}}+13.84$ & $1629.58^{\mathrm{B}} \pm 82.88$ \\
\hline 0.8 & $1284.02^{\mathrm{DEF}} \pm 64.94$ & $1072.3^{\mathrm{EFG}_{ \pm}}+8.52$ & $1178.13^{C_{ \pm}} \pm 38.90$ \\
\hline 10.0 & $790.72^{\mathrm{G}} \pm 61.82$ & $1007.0^{\mathrm{FG}} \pm 14.00$ & $898.83^{\mathrm{D}} \pm 0.06$ \\
\hline Diet-type overall & $1306.83^{\mathrm{B}} \pm 34.55$ & $1652.18^{\mathrm{A}} \pm 34.55$ & \\
\hline HSD & \multicolumn{2}{|c|}{96.678} & 244.82 \\
\hline HSD of interaction & \multicolumn{2}{|c|}{398.37} & \\
\hline
\end{tabular}

R1 $=70 \%$ forage: $30 \%$ concentrates; $2=60 \%$ forage: $40 \%$ concentrates; Means with different superscripts are significantly different $(p \leq 0.05)$.

suppression may explain the $\mathrm{CH}_{4}$ suppression. Protozoa are known to promote the methanogens with hydrogen, thus by the lower count of protozoa, the sustainability for methanogens [69]. The low number of protozoa was also observed throughout many other studies on various types of essential oils and plant-derived composites $[13,14,48,58,69]$. On the other hand, the effects on methanogens are not constant among the EO types, since such an effect depends on the composition of the oil [74].

The relevant connection of methanogens with protozoa and methane production in ruminants is similar as described by Kamra, et al. [75]. Such a close relationship is not generalized in all studies [38], while fatty acids may decrease methanogenesis directly by toxic properties on ruminal protozoa [61] and indirectly on methane-producing bacteria [76]. Thus, the inhibition of methane synthesis could be ascribed to a reduced archaea population due to protozoan inhibition. In contrast to extending the incubation time avoiding the depletion of substrate and allowing for a daily supply of additive, as under in vivo conditions. This line needs future research in order to be illustrated.

\section{Conclusions}

The present study provides evidence for the use of different levels of eucalyptus oil using a higher roughage-to-concentrate diet in order to mitigate methnogeneses under in vitro conditions. Methane production was negatively associated with increasing Euo in a dose-dependent manner. Also, the lower level $(2.0 \mathrm{~mL})$ of $\mathrm{EuO}$ used in the study significantly lowered methane production. Therefore, It is recommended to carry out an in vivo experiment in order to emphasize the effects of $\mathrm{EuO}$ on the ruminants.

\section{Acknowledgements}

The authors would like to offer special thanking to the Modern Agri-Industry Technology Research System of China (No. CARS-38) for providing financial support for this study.

\section{Conflict of Interest}

The authors declare no conflict of interest.

\section{References}

1. PIRONDINI M., COLOMBINI S., MELE M., MALAGUTTI L., RAPETTI L., GALASSI G., CROVETTO G.M. Effect of dietary starch concentration and fish oil supplementation on milk yield and composition, diet digestibility, and methane emissions in lactating dairy cows. J Dairy Sci, 98 (1), 357, 2015.

2. KARNATI S.K.R., SYLVESTER J.T., RIBEIRO C.V.D.M., GILLIGAN L.E., FIRKINS J.L. Investigating unsaturated fat, monensin, or bromoethanesulfonate in continuous cultures retaining ruminal protozoa. I. Fermentation, biohydrogenation, and microbial protein synthesisl. J Dairy Sci, 92 (8), 3849, 2009.

3. STOCKER T., QIN D., PLATTNER G., TIGNOR M., ALLEN S., BOSCHUNG J., NAUELS A., XIA Y., BEX B., MIDGLEY B. IPCC, 2013: Climate Change 2013: the Physical Science Basis. Contribution of Working Group I to the Fifth Assessment Report of the Intergovernmental Panel on Climate Change. Cambridge: Cambridge University Press; 2013.

4. SEJIAN V., HYDER I., EZEJI T., LAKRITZ J., BHATTA R., RAVINDRA J.P., PRASAD C.S., LAL R. Global Warming: Role of Livestock. In. Climate Change Impact on Livestock: Adaptation and Mitigation.Sejian V, Gaughan J, Baumgard L, Prasad C, eds: Springer India. New Delhi: 141, 2015. 
5. GERBER P., VELLINGA T., OPIO C., STEINFELD H. Productivity gains and greenhouse gas emissions intensity in dairy systems. Livest Sci, 139 (1-2), 100, 2011.

6. GERBER P.J., STEINFELD H., HENDERSON B., MOTTET A., OPIO C., DIJKMAN J., FALCUCCI A., TEMPIO G. Tackling Climate Change Through Livestock: A Global Assessment of Emissions and Mitigation Opportunities. Rome, Italy: Food and Agriculture Organization of the United Nations (FAO); 2013.

7. BEAUCHEMIN K.A., KREUZER M., O'MARA F., MCALLISTER T.A. Nutritional management for enteric methane abatement: a review. Aust J Exp Agric, 48 (2), 21, 2008.

8. JUNGBLUTH T., HARTUNG E., BROSE G. Greenhouse gas emissions from animal houses and manure stores. Nutr Cycl Agroecosys, 60 (1), 133, 2001.

9. FAO. World Food and Agriculture. Rome, Italy: Food and Agriculture Organization of the United Nations; 2013.

10. FAO. World Food and Agriculture. Rome, Italy: Food and Agriculture Organization of the United Nations; 2012.

11. WASHINGTON W., LEE K., ARENT D., AVERY S., CHAKOS A., DASZAK P., DIETZ T., EBI K.L., FISCHHOFF B., GRIMM N.B. Enhancing Participation in the US Global Change Research Program. Golden, CO (U S): National Renewable Energy Laboratory (NREL); 2016.

12. MCINTOSH F.M., WILLIAMS P., LOSA R., WALLACE R.J., BEEVER D.A., NEWBOLD C.J. Effects of essential oils on ruminal microorganisms and their protein metabolism. Appl Environ Microbiol, 69 (8), 5011, 2003.

13. BUSQUET M., CALSAMIGLIA S., FERRET A., KAMEL C. Plant extracts affect in vitro rumen microbial fermentation. J Dairy Sci, 89 (2), 761, 2006.

14. SALLAM S., BUENO I., BRIGIDE P., GODOY P., VITTI D., ABDALLA A. Efficacy of eucalyptus oil on in vitro ruminal fermentation and methane production. Options Mediterraneennes, 85 (85), 267, 2009.

15. BUSQUET M., CALSAMIGLIA S., FERRET A., CARDOZO P.W., KAMEL C. Effects of cinnamaldehyde and garlic oil on rumen microbial fermentation in a dual flow continuous culture. J Dairy Sci, 88 (7), 2508, 2005.

16. CHIQUETTE J., BENCHAAR C. Effects of different dose levels of essential oils compounds on in vitro methane production by mixed ruminal bacteria. J Dairy Sci. $1111 \mathrm{~N}$ Dunlap Ave, Savoy, IL 61874 USA: Am. Dairy Sci. Assoc.; 306 (Abst.) 2005.

17. KUMAR R., KAMRA D., AGARWAL N., CHAUDHARY L. Effect of eucalyptus (Eucalyptus globulus) oil on in vitro methanogenesis and fermentation of feed with buffalo rumen liquor. Anim Nutr Feed Technol, 9 237, 2009.

18. MANH N., WANAPAT M., URIYAPONGSON S., KHEJORNSART P., CHANTHAKHOUN V. Effect of eucalyptus (Camaldulensis) leaf meal powder on rumen fermentation characteristics in cattle fed on rice straw. Afr J Agric Res, 7, 2142, 2012.

19. KOUAZOUNDE J.B., JIN L., ASSOGBA F.M., AYEDOUN M.A., WANG Y., BEAUCHEMIN K.A., MCALLISTER T.A., GBENOU J.D. Effects of essential oils from medicinal plants acclimated to Benin on in vitro ruminal fermentation of Andropogon gayanus grass. J Sci Food Agric, 95 (5), 1031, 2015.

20. AGUERRE M.J., WATTIAUX M.A., POWELL J.M., BRODERICK G.A., ARNDT C. Effect of forageto-concentrate ratio in dairy cow diets on emission of methane, carbon dioxide, and ammonia, lactation performance, and manure excretion. J Dairy Sci, 94 (6), 3081, 2011.
21. MENKE K.H., STEINGASS H. Estimation of the energetic feed value obtained from chemical analysis and in vitro gas production using rumen fluid. Anim Res Dev, 28 (1), 7, 1988

22. NANON A., SUKSOMBAT W., YANG W.Z. Effects of essential oils supplementation on in vitro and in situ feed digestion in beef cattle. Anim Feed Sci Technol, 196 (Supplement C), 50, 2014.

23. ERWIN E., MARCO G., EMERY E. Volatile fatty acid analyses of blood and rumen fluid by gas chromatography. J Dairy Sci, 44 (9), 1768, 1961.

24. PRESTON T. Tropical Animal Feeding: A Manual For Research Workers (Animal Production and Health Paper No 126). Rome, Italy: Food and Agriculture Organization 1998.

25. SHINGFIELD K.J., JAAKKOLA S., HUHTANEN P. Effect of forage conservation method, concentrate level and propylene glycol on diet digestibility, rumen fermentation, blood metabolite concentrations and nutrient utilisation of dairy cows. Anim Feed Sci Technol, 97 (1), $1,2002$.

26. BLÜMMEL M., MAKKAR H.P.S., BECKER K. In vitro gas production: a technique revisited. J Anim Physiol Anim Nutr, 77 (1-5), 24, 1997.

27. KAMRA D.N., SAWAL R.K., PATHAK N.N., KEWALRAMANI N., AGARWAL N. Diurnal variation in ciliate protozoa in the rumen of black buck (Antilope cervicapra) fed green forage. Lett Appl Microbiol, 13 (3), 165, 1991

28. SAS. SAS User's Guide. Cary, NC: Statistical Analysis System Institute Inc.; 2000.

29. COBELlis G., YU Z., FORTE C., ACUTI G., TRABALZA-MARINUCCI M. Dietary supplementation of Rosmarinus officinalis L. leaves in sheep affects the abundance of rumen methanogens and other microbial populations. J Anim Sci Biotechnol, 7 (1), 27, 2016.

30. COBELLIS G., TRABALZA-MARINUCCI M., MARCOTULLIO M.C., YU Z. Evaluation of different essential oils in modulating methane and ammonia production, rumen fermentation, and rumen bacteria in vitro. Anim Feed Sci Technol, 215, 25, 2016.

31. COBELliS G., PETROZZI A., FORTE C., ACUTI G., ORRÙ M., MARCOTULLIO M., AQUINO A., NICOLINI A., MAZZA V., TRABALZA-MARINUCCI M. Evaluation of the effects of mitigation on methane and ammonia production by using Origanum vulgare L. and Rosmarinus officinalis $\mathrm{L}$. essential oils on in vitro rumen fermentation systems. Sustainability, 7 (9), 12856, 2015.

32. ROY D., TOMAR S., SIROHI S., KUMAR V., KUMAR M. Efficacy of different essential oils in modulating rumen fermentation in vitro using buffalo rumen liquor. Vet World, 7 (4), 213, 2014.

33. TATSUOKA N., HARA K., MIKUNI K., HARA K., HASHIMOTO H., ITABASHI H. Effects of the essential oil cyclodextrin complexes on ruminal methane production in vitro. Anim Sci J, 79 (1), 68, 2008.

34. PATRA A.K., YU Z. Effects of essential oils on methane production and fermentation by, and abundance and diversity of, rumen microbial populations. Appl Environ Microbiol, 78 (12), 4271, 2012.

35. PRINS R.A., VAN NEVEL C.J., DEMEYER D.I. Pure culture studies of inhibitors for methanogenic bacteria. Antonie Van Leeuwenhoek, 38 (1), 281, 1972.

36. SOLTAN Y.A., HASHEM N.M., MORSY A.S., EL-AZRAK K.M., EL-DIN A.N., SALLAM S.M. Comparative effects of Moringa oleifera root bark 
and monensin supplementations on ruminal fermentation, nutrient digestibility and growth performance of growing lambs. Anim Feed Sci Technol, 235, 189, 2018.

37. NOORIYAN S.M., ROUZBEHAN Y. Effect of essential oils of eucalyptus (Eucalyptus globulus Labill) and angelica (Heracleum persicum Desf. ex Fischer) on in vitro ruminal fermentation, protozoal population and methane emission using Afshari sheep inoculum. J Agr Sci Technol, 19, 553, 2017.

38. MACHMULLER A., SOLIVA C.R., KREUZER M. Methane-suppressing effect of myristic acid in sheep as affected by dietary calcium and forage proportion. $\mathrm{Br} \mathrm{J}$ Nutr, 90 (3), 529, 2003.

39. MAIA M.R.G., FONSECA A.J.M., OLIVEIRA H.M., MENDONÇA C., CABRITA A.R.J. The potential role of seaweeds in the natural manipulation of rumen fermentation and methane production. Sci Rep, 6, 32321, 2016.

40. MACHADO L., MAGNUSSON M., PAUL N.A., KINLEY R., DE NYS R., TOMKINS N. Dose-response effects of Asparagopsis taxiformis and Oedogonium sp. on in vitro fermentation and methane production. J Appl Phycol, 28 (2), 1443, 2016.

41. O'BRIEN M., NAVARRO-VILLA A., PURCELL P.J., BOLAND T.M., O'KIELY P. Reducing in vitro rumen methanogenesis for two contrasting diets using a series of inclusion rates of different additives. Anim Prod Sci, 54 (2), 141, 2014.

42. KLEVENHUSEN F., DECKARDT K., SIZMAZ Ö., WIMMER S., MURO-REYES A., KHIAOSA-ARD R., CHIZZOLA R., ZEBELI Q. Effects of black seed oil and Ferula elaeochytris supplementation on ruminal fermentation as tested in vitro with the rumen simulation technique (Rusitec). Anim Prod Sci, 55 (6), 73, 2015.

43. KHORRAMI B., VAKILI A.R., MESGARAN M.D., KLEVENHUSEN F. Thyme and cinnamon essential oils: Potential alternatives for monensin as a rumen modifier in beef production systems. Anim Feed Sci Technol, 200 8, 2015.

44. TOMKINS N.W., DENMAN S.E., PILAJUN R., WANAPAT M., MCSWEENEY C.S., ELLIOTT R. Manipulating rumen fermentation and methanogenesis using an essential oil and monensin in beef cattle fed a tropical grass hay. Anim Feed Sci Technol, 200 25, 2015.

45. SHARIFI M., BASHTANI M., NASERIAN A.A., FARHANGFAR H., EMAMI A. The effect of grapeseed oil on performance, rumen fermentation, antioxidant status and subcutaneous adipose fatty acid profile in lambs. J Anim Physiol Anim Nutr, 102 (1), 157, 2018.

46. PATRA A.K. Effects of essential oils on rumen fermentation, microbial ecology and ruminant production. Asian J Anim Vet Adv, 6, 416, 2011.

47. MACHEBOEUF D., MORGAVI D.P., PAPON Y., MOUSSET J.L., ARTURO-SCHAAN M. Dose-response effects of essential oils on in vitro fermentation activity of the rumen microbial population. Anim Feed Sci Technol, 145 (1), 335, 2008

48. LIN B., WANG J.H., LU Y., LIANG Q., LIU J.X. In vitro rumen fermentation and methane production are influenced by active components of essential oils combined with fumarate. J Anim Physiol Anim Nutr (Berl), 97 (1), 1, 2013.

49. COBEllis G., ACUTI G., FORTE C., MENGHINI L., DE VINCENZI S., ORRÙ M., VALIANI A., PACETTI D., TRABALZA-MARINUCCI M. Use of Rosmarinus officinalis in sheep diet formulations: Effects on ruminal fermentation, microbial numbers and in situ degradability. Small Ruminant Research, 126, 10, 2015.

50. HOOVER W.H. Chemical factors involved in ruminal fiber digestion1. J Dairy Sci, 69 (10), 2755, 1986.

51. JOHNSON K.A., JOHNSON D.E. Methane emissions from cattle. J Anim Sci, 73, 2483, 1995.

52. GERACI J.I., GARCIARENA A.D., GAGLIOSTRO G.A., BEAUCHEMIN K.A., COLOMBATTO D. Plant extracts containing cinnamaldehyde, eugenol and capsicum oleoresin added to feedlot cattle diets: Ruminal environment, short term intake pattern and animal performance. Anim Feed Sci Technol, 176 (1), 123, 2012.

53. VAKILI A.R., KHORRAMI B., MESGARAN M.D., PARAND E. The effects of thyme and cinnamon essential oils on performance, rumen fermentation and blood metabolites in holstein calves consuming high concentrate diet. Asian-Australas J Anim Sci, 26 (7), 935, 2013.

54. MORGAVI D.P., FORANO E., MARTIN C., NEWBOLD C.J. Microbial ecosystem and methanogenesis in ruminants. Animal, 4 (7), 1024, 2010.

55. BERGMAN E.N. Energy contributions of volatile fatty acids from the gastrointestinal tract in various species. Physiol Rev, 70 (2), 567, 1990.

56. TEKIPPE J.A., TACOMA R., HRISTOV A.N., LEE C., OH J., HEYLER K.S., CASSIDY T.W., VARGA G.A., BRAVO D. Effect of essential oils on ruminal fermentation and lactation performance of dairy cows. J Dairy Sci, 96 (12), 7892, 2013.

57. PATRA A.K., SAXENA J. A new perspective on the use of plant secondary metabolites to inhibit methanogenesis in the rumen. Phytochemistry, 71 (11-12), 1198, 2010.

58. THAO N., WANAPAT M., CHERDTHONG A., KANG S. Effects of eucalyptus crude oils supplementation on rumen fermentation, microorganism and nutrient digestibility in swamp buffaloes. Asian-Australas J Anim Sci 27, 46, 2014.

59. VAN NEVEL C.J., DEMEYER D.I. Control of rumen methanogenesis. Environ Monit Assess, 42 (1), 73, 1996.

60. PAWAR M.M., KAMRA D.N., AGARWAL N., CHAUDHARY L.C. Effects of essential oils on in vitro methanogenesis and feed fermentation with buffalo rumen liquor. Agric Res, 3 (1), 67, 2014.

61. ZHANG C.M., GUO Y.Q., WU Y.M., WANG J.K. Effect of octadeca carbon fatty acids on microbial fermentation, methanogenesis and microbial flora in vitro. Anim Feed Sci Technol, 146 (3), 259, 2008.

62. MCALLISTER T.A., CHENG K.J., OKINE E.K., MATHISON G.W. Dietary, environmental and microbiological aspects of methane production in ruminants. Can J Anim Sci, 76, 231, 1996.

63. CALSAMIGLIA S., BUSQUET M., CARDOZO P.W., CASTILLEJOS L., FERRET A. Invited review: Essential oils as modifiers of rumen microbial fermentation. J Dairy Sci, 90 (6), 2580, 2007.

64. BOOMKER E., CRONJÉ P. Ruminant Physiology: Digestion, Metabolism, Growth, and Reproduction. NY: CABI Publishing; 2000.

65. KNAPP J.R., LAUR G.L., VADAS P.A., WEISS W.P., TRICARICO J.M. Invited review: Enteric methane in dairy cattle production: Quantifying the opportunities and impact of reducing emissions. J Dairy Sci, 97 (6), 3231, 2014.

66. PANTHEE A., MATSUNO A., AL-MAMUN M., SANO $\mathrm{H}$. Effect of feeding garlic leaves on rumen fermentation, methane emission, plasma glucose kinetics, and nitrogen utilization in sheep. J Anim Sci Technol, 59 14, 2017. 
67. SEJIAN V., BHATTA R., SOREN N.M., MALIK P.K., RAVINDRA J.P., PRASAD C.S., LAL R. Introduction to Concepts of Climate Change Impact on Livestock and Its Adaptation and Mitigation. In. Climate Change Impact on Livestock: Adaptation and Mitigation.Sejian V, Gaughan J, Baumgard L, Prasad C, eds: Springer India.New Delhi: 1, 2015.

68. SARI M., FERRET A., CALSAMIGLIA S. Effect of $\mathrm{pH}$ on in vitro microbial fermentation and nutrient flow in diets containing barley straw or non-forage fiber sources. Anim Feed Sci Technol, 200, 17, 2015.

69. MORSY A.S., SOLTAN Y.A., SALLAM S.M.A., KREUZER M., ALENCAR S.M., ABDALLA A.L. Comparison of the in vitro efficiency of supplementary bee propolis extracts of different origin in enhancing the ruminal degradability of organic matter and mitigating the formation of methane. Anim Feed Sci Technol, 199, 51, 2015.

70. AEMIRO A., WATANABE S., SUZUKI K., HANADA M., UMETSU K., NISHIDA T. Effects of Euglena (Euglena gracilis) supplemented to diet (forage: concentrate ratios of 60:40) on the basic ruminal fermentation and methane emissions in in vitro condition. Anim Feed Sci Technol, 212, 129, 2016.

71. HRISTOV A.N., ROPP J.K., ZAMAN S., MELGAR A. Effects of essential oils on in vitro ruminal fermentation and ammonia release. Anim Feed Sci Technol, 144 (1-2), $55,2008$.

72. HEGARTY R.S., GOOPY J.P., HERD R.M. MCCORKELL B. Cattle selected for lower residual feed intake have reduced daily methane production. J Anim Sci, 85, 1479, 2007.

73. GILLES M., ZHAO J., AN M., AGBOOLA S. Chemical composition and antimicrobial properties of essential oils of three Australian Eucalyptus species. Food Chem, 119 (2), 731, 2010.

74. PATRA A.K., YU Z. Essential oils affect populations of some rumen bacteria in vitro as revealed by microarray (RumenBactArray) analysis. Front Microbiol, 6, 297, 2015.

75. KAMRA D.N., AGARWAL N., CHAUDHARY L.C. Manipulation of Rumen Microbial Ecosystem for Reducing Enteric Methane Emission in Livestock. In. Climate Change Impact on Livestock: Adaptation and Mitigation. Sejian V, Gaughan J, Baumgard L, Prasad C, eds: Springer India.New Delhi: 255, 2015.

76. NEWBOLD C.J., LASSALAS B., JOUANY J.P. The importance of methanogens associated with ciliate protozoa in ruminal methane production in vitro. Lett Appl Microbiol, 21 (4), 230, 1995. 